\title{
Duty to Address Climate Change Litigation Risks for Australian Energy Companies-Policy and Governance Issues
}

\author{
Prafula Pearce
}

Citation: Pearce, P. Duty to Address Climate Change Litigation Risks for Australian Energy Companies-Policy and Governance Issues. Energies 2021, 14, 7838. https://doi.org/10.3390/ en14237838

Academic Editor: Dalia Štreimikienè

Received: 17 October 2021

Accepted: 11 November 2021

Published: 23 November 2021

Publisher's Note: MDPI stays neutral with regard to jurisdictional claims in published maps and institutional affiliations.

Copyright: (C) 2021 by the author. Licensee MDPI, Basel, Switzerland. This article is an open access article distributed under the terms and conditions of the Creative Commons Attribution (CC BY) license (https:/ / creativecommons.org/licenses/by/ $4.0 /)$.
School of Business and Law, Edith Cowan University, Joondalup, WA 6027, Australia; p.pearce@ecu.edu.au

\begin{abstract}
The transition from fossil fuels to renewable energy requires cooperation from all, including corporations, shareholders, and institutional investors. The purpose of this paper is to explore climate change litigation risks for Australian energy companies and investors from a policy and governance perspective. Companies are increasingly reporting their climate policies to satisfy their shareholders and investor demands. In addition, the government and judiciary are making laws and decisions to support the Paris Agreement. This paper explores whether company directors can and, in some cases, should be considering the impact of climate change litigation risks on their business, or else risk breaching their obligation to exercise care and diligence under the Corporation Act 2001 (Cth, Australia). The paper concludes that in addition to reducing climate change litigation risks, Australian energy companies and institutional investment bodies that invest in Australian energy companies can make informed climate risk decisions by aligning their investments with the goal of net-zero or reduced emissions.
\end{abstract}

Keywords: energy companies; climate change litigation risks; directors duties; policy and governance

\section{Introduction}

The landmark Dutch court decision Milieudefensie v Shell [1] handed down in Hague District Court on 26 May 2021, held that Royal Dutch Shell PLC, a global energy company, had a duty of care to reduce $\mathrm{CO}_{2}$ emissions in its entire global value chain. The Court ordered Royal Dutch Shell to reduce the group's emissions by 45\% through Shell group's corporate policy. This decision has ramifications for energy companies around the world in assessing their climate change litigation risks.

The conceptual measure of global climate change litigation risk can be measured with two main databases that maintain details of climate litigation cases: the Climate Change Laws of the World (CCLW) database maintained by the Grantham Research Institute of Climate Change and the Environment [2]; and the United States Climate Litigation Database maintained by the Sabin Centre for Climate Change Law [3]. The Global trends in climate change litigation: 2021 report identified 1841 cases of climate change litigation around the world as of 31 May 2021, with the United States having the highest number of cases, totalling 1387, followed by Australia with 115 cases [4]. The forecast is for climate change litigation cases to grow in all countries, especially against corporations. However, the focus of this paper is not on global climate change cases, or the issues involved in the global cases against corporations as listed in Appendix B at the end of this paper. The global listings do, however, provide a conceptual measure of the climate change litigation risks. The purpose of this paper is to explore climate change litigation risks for Australian energy companies and how the directors can prevent the company from being exposed to this risk. Australian companies are increasingly reporting their climate policies to satisfy their shareholders and investor demands. In addition, the Australian government and judiciary are making laws and decisions to support the Paris Agreement.

The starting point for a discussion of global international obligations to climate change is the United Nations Framework Convention on Climate Change (UNFCCC). The UNFCCC has near-universal membership of 197 countries, including Australia, that have 
ratified the Convention. The UNFCCC has also established the Conference of the Parties (COP), which are the meetings of the participating countries to discuss climate change agenda. The most significant COP has been COP21, the 2015 Paris Agreement [5]. The Paris Agreement has changed from Kyoto's top-down approach of countries complying with legally binding commitments for emission reductions to a bottom-up approach whereby countries make their own commitment by pledging nationally determined contributions. This bottom-up approach recognises that adaptation is a global challenge faced by all. This means a broader responsibility than just through government policies. The responsibility is increasingly put on investors and corporations to make the right choices.

Climate change is also impacting institutional investors, as they are increasingly becoming aware of climate litigation risks, since investments in projects exposed to climate risks often flow into financial risks. Financial institutions may expose themselves to litigation by not addressing the Paris Agreement's objective of making "finance flows consistent with a pathway towards lower greenhouse gas emissions and climate resilient development [6]". The reason for this is that climate litigation can expose financial institutions to stranded assets from abandoned projects if the judge orders the project to halt due to associated climate risks. It is not possible to completely divest from these risks. However, the message from the litigated cases is being responded to through tangible investment decisions. The message of this paper is to make the financial institutions and corporations aware of the litigation risks if they ignore climate risks in investment and business decisions. In addition, they can become exposed to litigation for breaches of the Australian Corporations Act 2001 (Cth, Australia) and climate legislation, as discussed below.

This review paper is in five parts. Following this brief introduction, Section 2 explores the climate change litigation risks faced by energy and superannuation companies in Australia that invest in nonrenewable energy. Section 3 then examines whether climate change risks may be relevant to an Australian company director's duty of care and diligence under s180(1) of the Corporations Act 2001 (Cth, Australia) to the extent that they interact with the interests of the company, followed by Section 4, which points to actions that the directors of Australian energy companies can take to minimise the impact of climate change litigation risks on their businesses and prevent the risk of breaching their directors' duties under the Corporations Act 2001 (Cth, Australia). Part 5 concludes the paper, stating that the role of directors is to manage physical and transitional risks and test company strategy against climate change scenarios, including timely flow of climate-change-related information from management to the board.

\section{Climate Change Litigation Risks for Both Energy and Superannuation Companies in Australia}

Companies involved in the production of energy resources, by the very nature of their operations, should be considering climate change litigation risk as a potential business risk when their directors and managers make management decisions.

Major companies and financial institutions in Australia are increasingly being challenged in their investment decisions that impact upon climate change, as shown in selected cases listed in the Appendix A of this paper. Some of the litigation issues that have impacted climate change risks for energy and superannuation companies are:

- Shareholders seeking disclosure from the Commonwealth Bank of Australia on internal documents under the Corporations Act 2001 (Cth, Australia) relating to projects to ascertain whether the projects comply with the goals of the Paris Agreement [7];

- An institution (the Australasian Centre for Corporate Responsibility) challenging whether a company involved in oil and gas made a false and misleading representation about its net-zero emissions plan on the basis that natural gas is a clean fuel [8];

- $\quad$ An institution (Environment Victoria Inc.) challenging whether the Environmental Protection Authority had correctly considered the Climate Change Act when a new license for coal-burning power stations that failed to lower the limits of GHG emissions was granted [9]; 
- Climate activist Sharma (a teenager) challenging the Australian government's approval of a coal mine on the basis that the Minister owes a duty of care to avoid personal injury to children [10];

- An Australian government bondholder suing the Australian government for failure to disclose climate risks, and hence misleading and deceiving investors by failing to disclose such risks [11];

- A member of an Australian pension fund alleging that the Retail Employees Superannuation Trust (REST) failed to provide information relating to climate change business risks and any plans to address those risks, and hence violated the Corporations Act 2001 (Cth, Australia) [12];

- The Minister for the Environment and Energy not taking into consideration the physical impacts of climate change on the Great Barrier [13];

- An application to open a new open cut mine was rejected, and one of the grounds for rejection was the impact of the mine on climate change [14].

Australia is a signatory to the Paris Agreement [15], whereby it agrees to contribute to keeping the global average temperature risk to $1.5^{\circ}$ to $2^{\circ}$ by a reduction in greenhouse gas emissions, namely carbon dioxide and methane from the burning of coal. This causal factor is well known to the judiciary, who have commented that greenhouse emissions "adversely impact upon measure to limit dangerous anthropogenic climate change [16]" That is, the burning of extracted coal, with the subsequent release of greenhouse gases, will have a cumulative effect on climate change globally [17]. As such, Australia has adopted a Carbon Budget Approach in order to highlight trade-offs involved between actions taken now to reduce greenhouse gas emissions and those made necessary later [18]. The carbon budget approach measures carbon sources against carbon sinks. In the case of Gloucester Resources Limited $v$ Minister for Planning [14], the Federal Court of Australia defined this approach as being based on the close interplay between planetary temperature warming and the cumulative effect of anthropogenic emissions. The Court argued that this approach is a "scientifically robust approach to estimating the level of greenhouse gas emission reductions required to meet a desired temperature target". It was argued by the appellant that if the respondent refused authority for the mine site to be developed and opened, any savings to the emissions total would be negated globally, as another mine in a (probably lesser-developed) country would open in any event with less stringent supervision, and replace the emissions saved in Australia. The court found that this "market substitution" was a flawed argument to make, as it found there was no certainty of mines in other areas opening up. In fact, the strong position taken by Australia in this scenario could lead those lesser-developed countries to "follow suit". The US courts have also stated that the "market substitution" theory is one that is arbitrary, capricious, and irrational [19].

Investment companies, such as those in superannuation, are equally put at litigation risk for lack of climate change considerations in their investment decisions. Investments in coal-producing mines are no longer seen as a viable option, which could lead to such investments being stranded [20], with courts willing to directly link the burning of fossil fuels to climate change [14]. As a result, private corporations involved in the finance sector are being held to account over expectations of disclosing to shareholders corporate consideration relating to climate change [21]. Where they fail to meet the necessary level of specific disclosure, they face unwanted scrutiny, either through regulatory bodies or through activist third-parties [22].

In Mark McVeigh v Retail Employees Superannuation Pty Ltd. [23], a private suit brought against a major superannuation fund, whereby a shareholder sought specific climate change disclosure information, as that information was nonspecific and inadequate in detail. Declaratory relief was sought in the suit because the fund had violated the Corporations Act 2001 (Cth, Australia) by failing to disclose the information, and further, an injunction was sought against the fund to produce the sought information. It was further alleged that the fund breached the Superannuation Industry (Supervision) Act [24], in that a trustee for the fund would have been able to ensure that the investment managers could have produced 
the required information, and further that such managers could ensure that such climate change specific information could be made easily accessible to beneficiaries of the fund, and thereby comply with recommendation of the task force on Climate-Related Financial Disclosures [12]. Justice Perram commented, during the maximum costs order hearing (paragraph 9) that:

"The case appears to raise a socially significant issue about the role of superannuation trusts and trustees in the current public controversy about climate change. It is legitimate to describe the Applicant's litigation as being of a public interest nature [12]."

The case was settled just before the hearing was due to commence. However, the case points towards a conclusion that "financial institutions, corporates and global investment funds, are likely to face increased scrutiny from their stakeholders with respect to their climate change policies [25]".

Superannuation investments are being adversely impacted by climate change from the transition of economic reliance on fossil fuels and the physical damage arising from the natural disasters that are becoming all the more common [26]. Investing in such industry that cumulatively impacts on climate change could be seen as not acting in the best interests of the investor [27]. Breach of fiduciary duties could then be alleged. One such fund, Unisuper, which operates an AUD 85 million fund with more than 450,000 members, has refused to divest its AUD 170 million investment in coal companies or its AUD 7.8 million investment in other fossil fuel companies, stating that selling the holdings would deprive them of the right to influence the industries in making a change. However, this is becoming the exception and not the rule, with the Australian Centre of Corporate Responsibility finding an increasing number of shareholder proposals for investments in fossil fuel mining companies being rejected by Australian super funds [26].

Regulators in Australia are being guided by the recommendations from the UNFCCCapproved Task Force on Climate-Related Financial Disclosures (TCDF). The TCDF's recommendations direct a company's climate change risk practices to four areas for adequate oversight and operations: governance, strategy, risk management, and metrics and targets [28]. The TCFD framework recommendations have been endorsed by the regulators in Australia, including the Reserve Bank of Australia (RBA), Australian Prudential Regulation Authority (APRA), the Australian Council of Superannuation Investors' (ACSI), and the Australian Securities and Investment Commission (ASIC) [29].

APRA currently supervises AUD 7.7 trillion in assets for Australian depositors, policyholders, and superannuation fund members. APRA has been raising awareness of climate-related risks to the financial sector and is developing prudential practice guidance that will be released at the end of 2021. The APRA guidance has adopted the TCDF recommendations [30].

The ACSI Governance Guidelines (2019) expect companies to disclose their approach to climate-related risks by adopting the TCFD and align their corporate strategy to the Paris Agreement (net zero by 2050), and the council may direct its members to vote against directors that fall short of managing their climate-related risks [31].

The company directors of energy companies should also observe the ASIC Commissioner's direction to have appropriate governance structures in place to manage climaterelated risk and comply with reporting requirements established by the TCDF, and thereby provide their shareholders with reliable and useful information on the exposure to material climate-related risks and opportunities [32].This clear shift in focus in forcing compliance with strategies to meet the Paris Agreement's emission levels is beginning to involve the judiciary in enforcing that compliance and reporting obligations against companies that either directly or indirectly have an impact on the emission of greenhouse gases and hence there is a rise in climate change ligitation. 
Ultimately, times have changed, and all corporations that directly or indirectly do business with those who emit greenhouse gases have an ever-increasing mandate to report upon and disclose such transactions. In addition to enforcement through Australian regulatory bodies, individuals (and activist groups) are obtaining greater recognition for standing in courts to litigate against companies that fail to consider or adequately disclose climate change risks.

In order to avoid unnecessary litigative risks, companies across the board, especially energy companies, should assess how their interests affect the possibility of changes to climatic conditions.

\section{Relevance of Climate Change Risks on Director's Duty of Care and Diligence}

As discussed above, Australian regulatory bodies have increasingly begun to focus on potential obligations of directors regarding environmental issues, such as climate change risks, in their management decisions. In Australia, the obligations to consider climate change risks also arise from Section 180 (1) of the Corporations Act 2001 (Cth, Australia), which requires company directors to exercise their powers with the degree of care and diligence that would reasonably be expected of a director in the same position and responsibility of a corporation in those circumstances [33]. The degree of care refers to the degree of attention and thorough conduct necessary to act for the benefit of the company [34]. Diligence refers to the consistent attention a director pays to their responsibilities and in maintaining the minimum standards expected of that role [35]. An objective reasonable standard is used in determining a breach of the duty, and similar to other risks, climate risks would also be weighed against the magnitude of the risk of harm and the probability of it occurring; the seriousness of the resulting loss, should the harm occur; and the expense, difficulty, and inconvenience of taking alleviating action [36].

In assessing the climate change risks regarding directors' duty of care and diligence, it should be noted that the business judgement rule in s180 (2) of the Corporations Act 2001 (Cth, Australia) is limited in application where "decisions" are made by a director to act or to not act. Those who fail to make a decision or to turn their mind to the issues presented by climate change will not be afforded the protection of the business judgment rule [37].

Directors' duties and their relevance to climate change risk were considered by the Centre for Policy Development and the Future Business Council, which commissioned the Australian Legal Memorandum of Opinion "Climate Change and Director's Duties" [38]. The report confirmed that climate change risks are capable of representing a risk to the interests of an Australian company and are relevant to a director's duty of care [39]. In addition to the Hutley 2016 and 2019 opinions, a further 2021 Supplementary Memorandum of Opinion was issued as follows:

"In 2016, our focus was the existence of the duty; that is, what directors could and should be doing on climate change to discharge their duty of due care and diligence. That is now uncontroversial. In 2019, we observed that the risk of liability for directors on this front was rising exponentially. In 2021, it appears to us that the focus is increasingly on how the duty is discharged" [40].

The Hutley 2021 report states that directors' disclosures of climate actions should be accurate, as inaccurate statements could lead to misleading conduct commonly known as "greenwashing" [40].

As regards the extent to which climate change risks are of relevance to the care and diligence duty under s180 of the Corporations Act 2001 (Cth, Australia), the authors of the Hutley report took the view that such risks are relevant to the extent that they intersect with the interests of the company [39]. Particular emphasis was placed on the issue of foreseeability, and the potential ramifications for directors who fail to address foreseeable risks [38]. The general position in Australian law is that a risk is foreseeable so long as it is not far-fetched or fanciful [41], meaning a risk that is unlikely may nonetheless be entirely foreseeable. Furthermore, a plaintiff is not required to prove that a director's conduct in respect to a foreseeable risk resulted in actual loss [33]. Thus, any harm incurred 
by a company because of failure to mitigate their response to the risk could be deemed foreseeable by a court, as the risks associated with both climate change and attenuating global warming are "significant and well publicised" [39], not "far-fetched or fanciful". Whilst climate change risks have historically been viewed as a future or nonfinancial problem [42], the Hutley supplementary memorandum contends that intersection between such risks and the interests of companies, particularly in sectors such as energy resources and institutional investment, is inevitable. Thus energy company directors should take heed of the Hutley opinion that directors of Australian listed companies can potentially be liable for material harm to their company, should they fail to adequately consider and disclose foreseeable climate change risks [43].

The next section explores how the directors of energy companies may be able to minimise the impact of climate change litigation risks on their businesses, and also avert the risk of breaching their obligations to exercise care and diligence.

\section{Direction for Energy Company Directors to Minimise the Impact of Climate Change Litigation Risks}

Climate change risks can be classified as transition risks and physical risks [43]. The physical risks brought about by climate change include increased temperatures, change in rainfall patterns, and an increase of frequency and/or intensity of extreme weather events such as heatwaves, drought, storms, flooding, and rising sea levels [44]. A prudent director of an energy company should include these factors in the future planning of the business. The financial implications of physical risks should also be considered, and this may include damage to assets [45]. Transitional risks refer to the regulatory risks and opportunities associated with carbon emissions and related pollutants. Examples include costs associated with retooling to fit within a low-carbon transition. Transitional impact also includes the risks of litigation, exposure to damage claims, operational disruption, and costs of enforcement of disclosure obligations and potential reputational damage [46].

A director of an energy company should also be aware that these climate change risks include advances in scientific discoveries and the attitudes of Australian regulators and investor groups. The courts will take into account all of these matters when deciding if a director of an energy company has appropriately responded to the risk and made proper disclosure of it [39]. The Australian Securities and Investment Commission (ASIC) published a report in 2018 suggesting that directors of listed companies should consider short-term and long-term climate change risk when assessing risks to a company [47].

The courts will, of course, balance the climate risk posed with potential benefits to the corporation [38], but the corporation needs to heed the commercial consequences that will flow from any breach of duty, as any adverse scrutiny could lead to reputational damage [48] and possible corporate failure.

Though no court in Australia has yet specifically ruled on whether a director's duty under s180 of the Corporations Act 2001 (Cth, Australia) includes the appropriation of climate change risk, it has been reported by Kenneth Hayne QC that the duty to act in the best interest of the corporation incorporates climate change considerations [49]. The 2019 Hutley legal opinion that views climate change as being a "foreseeable risk to the interest of a company [39]", has been endorsed by the Australian Securities and Investment Commission (ASIC) as being legally sound and accurate as it pertains to prevailing laws in Australia [50]. It has also been supported by the ASX Corporate Governance Council, the Australian Prudential Regulation Authority, the Australian Accounting Standards Board, and the Auditing and Assurance Standards Board.

The Hutley 2021 opinion provides the following practical steps for directors:

- Develop a net-zero strategy that is integrated with a company's operational strategy;

- Document and test the assumptions underpinning the strategy, including any offsets;

- $\quad$ Explain which emissions are included in the strategy and express the scope and timing

of the commitment; and 
- Disclose promptly the circumstances that affect the strategy from being accomplished [40].

The number of recent climate change cases in the courts points to a conclusion that climate change is a serious factor for consideration for a director of an energy company in demonstrating the exercise of the duty of care and diligence in the management of the corporation. Company directors may risk breaching their duty of care and diligence if they fail to consider the impact of climate change risks on their businesses. The director has a duty to consider the gravity (seriousness) of risk, probability of outcome, cost of prevention, and other obligations when deciding whether to incorporate climate change risks into their decision making. This means that the director must consider climate change risks at least to the degree of determining whether they are a relevant factor in the decision they are making. Failure to contemplate climate change risks, and the reporting thereof, could place the company at the risk of facing litigation.

\section{Conclusions}

The pathway to avoid the risk of Australian energy company directors breaching duties relating to climate change litigation risks is to follow the Hutley 2021 recommendations, and in particular to include more detailed disclosures in line with TCDF recommendations. Directors should consider who may be relying on climate-related disclosures. They should have systems in place to regularly check whether appropriate disclosures pertaining to climate change have been made and determine the accuracy and completeness of climate-related disclosures.

In addition, the boards of energy companies should regularly consider climate change matters and risks, including the management of physical and transitional risks, and test company strategy against climate change scenarios, including timely flow of material; i.e., climate-change-related information from management to the board.

In addition to reducing climate change litigation risks, corporations and institutional investment bodies can provide support to their government by making informed climate risk decisions and by aligning their investments with the goal of net-zero or reduced emissions. However, this is not an easy task for directors of energy companies to reduce litigation risk exposure by setting short, medium, and long-term emission-reduction targets that align to the Paris Agreement and the objective of net-zero emissions by 2050. Energy company directors have to continue to attract investments from investors and also play a major part in global reduction of emissions by pledging major emission reductions in support of the Paris agreement, as many large companies have already done [51].

Funding: This research received no external funding.

Institutional Review Board Statement: Not applicable.

Informed Consent Statement: Not applicable.

Data Availability Statement: Not applicable.

Acknowledgments: The author would like to acknowledge the assignment research of the students of Environmental Law in 2 Semester 2020 at the School of Business and Law, Edith Cowan University, in particular Clifford Warner and Alicia Nowak.

Conflicts of Interest: The authors declare no conflict of interest. 


\section{Appendix A}

Table A1. Selected climate change litigation in Australia.

\begin{tabular}{|c|c|c|c|c|}
\hline Case Name & Filing Date & Court & $\begin{array}{l}\text { Status as of } \\
\text { October } 2021\end{array}$ & $\begin{array}{l}\text { Summary of Finding } \\
\text { Relevant to Climate Change }\end{array}$ \\
\hline $\begin{array}{l}\text { Abrahams v } \\
\text { Commonwealth Bank } \\
\text { of Australia }\end{array}$ & 2021 & $\begin{array}{l}\text { Federal Court of } \\
\text { Australia }\end{array}$ & Pending & $\begin{array}{l}\text { Shareholders of Commonwealth Bank } \\
\text { of Australia brought an action to obtain } \\
\text { documents to verify whether the bank } \\
\text { carried out an environmental } \\
\text { assessment of its involvement in } \\
\text { projects in line with the Paris agreement. }\end{array}$ \\
\hline $\begin{array}{l}\text { Australasian Centre for } \\
\text { Corporate } \\
\text { Responsibility v Santos }\end{array}$ & 2021 & $\begin{array}{l}\text { Federal Court of } \\
\text { Australia }\end{array}$ & Pending & $\begin{array}{l}\text { The Environmental Defenders Office } \\
\text { challenged the company Santos' claims } \\
\text { of net-zero emissions target by } 2040 \text {. }\end{array}$ \\
\hline $\begin{array}{c}\text { Complaint to Ad } \\
\text { Standards on HSBC's } \\
\text { Great Barrier Reef ad }\end{array}$ & 2021 & Ad Standards & Pending & $\begin{array}{l}\text { An action challenging HSBC's } \\
\text { greenwashing practice on its promotion } \\
\text { of Great Barrier Reef protection. }\end{array}$ \\
\hline $\begin{array}{l}\text { Environment Victoria } \\
\text { vs. the EPA et al. }\end{array}$ & 2021 & $\begin{array}{l}\text { Victorian } \\
\text { Supreme Court }\end{array}$ & Pending & $\begin{array}{l}\text { Environment Victoria is challenging } \\
\text { the EPA for failing to protect the } \\
\text { community by granting license } \\
\text { to operate coal mines. }\end{array}$ \\
\hline $\begin{array}{l}\text { Sharma and others v } \\
\text { Minister for the } \\
\text { Environment }\end{array}$ & 2020 & $\begin{array}{l}\text { Federal Court of } \\
\text { Australia }\end{array}$ & Appeal Pending & $\begin{array}{l}\text { Climate activist Sharma (a teenager) is } \\
\text { challenging the Australian Government } \\
\text { for approving a coal mine on the basis } \\
\text { that the Minister owes a duty of care to } \\
\text { avoid personal injury to children. }\end{array}$ \\
\hline $\begin{array}{l}\text { O'Donnell v } \\
\text { Commonwealth }\end{array}$ & 2020 & $\begin{array}{l}\text { Federal Court of } \\
\text { Australia }\end{array}$ & Pending & $\begin{array}{l}\text { Action brought by a holder of } \\
\text { Austrtalian bonds against the } \\
\text { Commonwealth Government for } \\
\text { failure to disclose climate risks. }\end{array}$ \\
\hline $\begin{array}{l}\text { Youth Verdict v } \\
\text { Waratah Coal }\end{array}$ & 2020 & $\begin{array}{l}\text { Queensland Land } \\
\text { Court }\end{array}$ & Pending & $\begin{array}{l}\text { Youth Verdict Limited application } \\
\text { for objection to develop a thermal coal } \\
\text { mine in Galilee Basin. }\end{array}$ \\
\hline
\end{tabular}

\section{KEPCO Bylong}

Australia v Independent Planning

Commission and

Bylong Valley

Protection Alliance

$2019 \quad \begin{aligned} & \text { New South Wales } \\ & \text { Court of Appeal Decided }\end{aligned}$

The Independent Planning Commission has discretion to reject the planning application of a coal mine on the basis of climate change impacts.

\section{McVeigh v Retail \\ Employees}

Superannuation Trust
2018

Federal Court of
Australia

Decided
A pension fund member sued a superannuation fund, who settled the case and agreed to take into considration climate risks and reach net zero by 2050 .

\begin{tabular}{|c|c|c|c|}
\hline $\begin{array}{c}\text { Australian } \\
\text { Conservation } \\
\text { Foundation } \\
\text { Incorporated v Minister } \\
\text { for the Environment } \\
\text { and Energy }\end{array}$ & 2017 & $\begin{array}{c}\text { Federal Court of } \\
\text { Australia }\end{array}$ & Decided \\
\hline $\begin{array}{l}\text { Gloucester Resources } \\
\text { Limited v Minister } \\
\text { for Planning }\end{array}$ & 2017 & $\begin{array}{c}\text { New South Wales } \\
\text { Land and } \\
\text { Environment } \\
\text { Court }\end{array}$ & Decided \\
\hline
\end{tabular}

The appeal related to the Minister for the Environment and Energy not taking into consideration the physical impacts of climate change on the Great Barrier Reef.

An application to open a new open cut mine was rejected, and one of the grounds for rejection was the impact of the mine on climate change. 


\section{Appendix B}

Table A2. Selected non-US climate change litigation cases against corporations.

\begin{tabular}{|c|c|c|}
\hline Country & Name of Case & Issue \\
\hline Australia & $\begin{array}{l}\text { Mullaley Gas and Pipeline Accord Inc v } \\
\text { Santos NSW (Eastern) Pty Ltd. }\end{array}$ & $\begin{array}{l}\text { Challenge to the development consent of the Narrabri Gas } \\
\text { Project by the Independent Planning Commission. }\end{array}$ \\
\hline UK & $\begin{array}{l}\text { ASA Ruling on Ryanair Ltd. } \\
\text { t/a Ryanair Ltd. }\end{array}$ & $\begin{array}{l}\text { Challenge to the accuracy of advertisement relating to } \\
\text { emissions from an airline. }\end{array}$ \\
\hline Germany & Barbara Metz et al. v Wintershall Dea AG & $\begin{array}{l}\text { Petitioners challenging car companies' emissions by } \\
\text { producing internal combustion engines. }\end{array}$ \\
\hline Germany & $\begin{array}{l}\text { Deutsche Umwelthilfe (DUH) v } \\
\text { Mercedes-Benz AG }\end{array}$ & $\begin{array}{l}\text { Petitioners challenging car companies' emissions by } \\
\text { producing internal combustion engines. }\end{array}$ \\
\hline Germany & Deutsche Umwelthilfe (DUH) v BMW & $\begin{array}{l}\text { Petitioners challenging car companies' emissions by } \\
\text { producing internal combustion engines. }\end{array}$ \\
\hline Australia & $\begin{array}{l}\text { Complaint to Ad Standards on HSBC's } \\
\text { Great Barrier Reef ad }\end{array}$ & $\begin{array}{l}\text { An action challenging HSBC's greenwashing practice on its } \\
\text { promotion of Great Barrier Reef protection. }\end{array}$ \\
\hline Australia & $\begin{array}{l}\text { Abrahams v Commonwealth } \\
\text { Bank of Australia (2021) }\end{array}$ & $\begin{array}{c}\text { Shareholders of Commonwealth Bank of Australia brought an } \\
\text { action to obtain documents to verify whether the bank carried } \\
\text { out an environmental assessment of its involvement in } \\
\text { projects in line with the Paris Agreement. }\end{array}$ \\
\hline Brazil & $\begin{array}{l}\text { Instituto Preservar et al. v Copelmi } \\
\text { Mineração Ltd.a. and IBAMA }\end{array}$ & $\begin{array}{l}\text { Whether precautionary measures should be taken to develop } \\
\text { open-pit coal mining. }\end{array}$ \\
\hline Australia & $\begin{array}{l}\text { Australasian Centre for Corporate } \\
\text { Responsibility v Santos }\end{array}$ & $\begin{array}{l}\text { The Environmental Defenders Office challenged the company } \\
\text { Santos' claims of net-zero emissions target by } 2040 \text {. }\end{array}$ \\
\hline New Zealand & $\begin{array}{l}\text { Complaint by Lawyers for Climate to the } \\
\text { Advertising Standards Board }\end{array}$ & Greenwashing advertisement challenged. \\
\hline South Africa & $\begin{array}{l}\text { South Durban Community } \\
\text { Environmental Alliance v Minister of } \\
\text { Environment and Others }\end{array}$ & $\begin{array}{l}\text { South Africa's authorization of oil exploration challenged on } \\
\text { the grounds of climate violations. }\end{array}$ \\
\hline Brazil & Ministério Público Federal v de Rezende & Deforestation in the Amazon challenged. \\
\hline UK & R v Bramwell et al. ("The Shell Six case") & Environmental protestors charged for criminal damage. \\
\hline UK & Attorney General v Crosland & $\begin{array}{l}\text { Unregistered barrister convicted of criminal contempt of court } \\
\text { for breaching a court embargo of publication on a court } \\
\text { judgement with an environmental issue. }\end{array}$ \\
\hline Belgium & ClientEarth v Belgian National Bank & $\begin{array}{l}\text { NGO seeks to stop the bank from directing its capital to } \\
\text { programmes that affect climate. }\end{array}$ \\
\hline France & Envol Vert et al. v Casino & $\begin{array}{l}\text { NGO is suing a French supermarket for seeking supplies of } \\
\text { cattle from areas that impact the environment. }\end{array}$ \\
\hline France & $\begin{array}{l}\text { Friends of the Earth et al. v Prefect of of } \\
\text { Bouches-du-Rhône and Total }\end{array}$ & $\begin{array}{l}\text { Challenging a permit to operate a biorefinery on the basis of } \\
\text { environmental impact. }\end{array}$ \\
\hline Australia & $\begin{array}{l}\text { Conservation Council of Western } \\
\text { Australia v Hatton and Woodside }\end{array}$ & $\begin{array}{l}\text { Challenges to approval of gas projects without full climate } \\
\text { impact assessment. }\end{array}$ \\
\hline Argentina & $\begin{array}{l}\text { Carballo et al. v MSU S.A., UGEN S.A., } \\
\qquad \& \text { General Electric }\end{array}$ & Whether environmental impact assessment was flawed. \\
\hline Argentina & OAAA v Araucaria Energy SA. & Whether environmental impact assessment was flawed. \\
\hline Argentina & $\begin{array}{l}\text { Hahn et al. v Araucaria Energy Sociedad } \\
\text { Anonima }\end{array}$ & Whether environmental impact assessment was flawed. \\
\hline Argentina & Hahn et al. v APR Energy S.R.L & Whether environmental impact assessment was flawed. \\
\hline Argentina & $\begin{array}{c}\text { FOMEO v MSU S.A., Rio Energy S.A., } \\
\text { \& General Electric }\end{array}$ & Whether environmental impact assessment was flawed \\
\hline
\end{tabular}


Table A2. Cont.

\begin{tabular}{|c|c|c|}
\hline Country & Name of Case & Issue \\
\hline Australia & $\begin{array}{c}\text { Friends of Leadbeater's Possum Inc v } \\
\text { VicForests (No 3) }\end{array}$ & Conservation group seeking protection of the environment. \\
\hline Australia & $\begin{array}{l}\text { EH v Queensland Police Service; GS v } \\
\text { Queensland Police Service }\end{array}$ & $\begin{array}{l}\text { Climate protesters' convictions for } \\
\text { protesting against coal mine. }\end{array}$ \\
\hline Australia & $\begin{array}{c}\text { Australasian Centre for Corporate } \\
\text { Responsibility (ACCR) v Commonwealth } \\
\text { Bank of Australia }\end{array}$ & Shareholders sought climate disclosures. \\
\hline Canada & Trans Mountain Pipeline ULC v Mivasair & Pipeline protesters sought to assert necessity defense \\
\hline Poland & $\begin{array}{l}\text { Development YES-Open-Pit Mines NO } \\
\text { v Group PZU S.A. }\end{array}$ & $\begin{array}{l}\text { NGO claimed that Polish NCP did not observe OECD } \\
\text { National Guidelines relating to environmental protection. }\end{array}$ \\
\hline Australia & Youth Verdict v Waratah Coal & $\begin{array}{l}\text { Youth Verdict Limited application for objection to develop a } \\
\text { thermal coal mine in Galilee Basin. }\end{array}$ \\
\hline Germany & Germanwatch vs. Volkswagen & Whether Volkswagen violated climate obligations. \\
\hline Norway & $\begin{array}{l}\text { Norwegian Climate Network et al. v } \\
\text { Statoil }\end{array}$ & Claim that oil sands must not be exploited for climate stability. \\
\hline Netherlands & $\begin{array}{l}\text { BankTrack and Friends of the Earth } \\
\text { Netherlands v ING Bank }\end{array}$ & $\begin{array}{l}\text { Complaint against the bank for not committing to } \\
\text { OECD guidelines on climate change. }\end{array}$ \\
\hline Japan & $\begin{array}{c}\text { Market Forces v SMBC, MUFG and } \\
\text { Mizuho }\end{array}$ & $\begin{array}{l}\text { Complaint against funding of coal mines in } \\
\text { Vietnam by Japanese banks. }\end{array}$ \\
\hline Brazil & $\begin{array}{l}\text { Federal Environmental Agency (ibama) v } \\
\text { Siderúrgica São Luiz Ltd. }\end{array}$ & $\begin{array}{l}\text { Action against steel company to prevent deforestation } \\
\text { by not sourcing coal. }\end{array}$ \\
\hline Poland & Greenpeace Poland v PGE Giek & Greenpeace sues to stop fossil fuel investment. \\
\hline New Zealand & $\begin{array}{l}\text { Smith v Fronterra Co-Operative Group } \\
\text { Limited \& Ors }\end{array}$ & $\begin{array}{l}\text { Maori heritage spokesperson claims company owes } \\
\text { duty to cease contributing to climate change. }\end{array}$ \\
\hline Japan & $\begin{array}{l}\text { Citizens' Committee on the Kobe } \\
\text { Coal-Fired Power Plant v Kobe Steel. } \\
\text { Ltd., et al. }\end{array}$ & Construction of coal-fired plant was challenged. \\
\hline Switzerland & Credit Suisse Protesters v Credit Suisse & Activists protesting for Credit Suisse to heed climate change. \\
\hline UK & ClientEarth v BP. & $\begin{array}{l}\text { Whether BP misled the public about its } \\
\text { presentation of low-carbon activities. }\end{array}$ \\
\hline France & Friends of the Earth et al. v Total. & $\begin{array}{l}\text { Whether company owes duty of vigilence to assess } \\
\text { threats of oil projects to human rights. }\end{array}$ \\
\hline \multirow[t]{2}{*}{ Argentina } & $\begin{array}{l}\text { Mapuche Confederation of Neuquén v } \\
\text { YPF. }\end{array}$ & $\begin{array}{l}\text { Dispute about dumping dangerous waste } \\
\text { and harming the environment. }\end{array}$ \\
\hline & R v Roberts & Protestors dispute about anti-fracking. \\
\hline UK & R v Basto & Climate activists challenged for protesting near airport. \\
\hline Poland & $\begin{array}{l}\text { ClientEarth v Polska. Grupa } \\
\text { Energetyczna. }\end{array}$ & $\begin{array}{l}\text { Seeking Europe's largest power plant operator } \\
\text { to reduce emissions. }\end{array}$ \\
\hline France & The Take Down Macron campaign Cases & $\begin{array}{l}\text { Activists challenged for protesting against } \\
\text { France's failure to meet climate targets. }\end{array}$ \\
\hline France & Notre Affaire a Tous and Others v Total. & Whether climate change risks were adequately reported. \\
\hline Netherlands & Milieudefensie et al. v Shell & $\begin{array}{l}\text { Whether a multinational corporation is obliged to curtail } \\
\text { carbon dioxide emissions. }\end{array}$ \\
\hline Poland & ClientEarth v ENEA & Breach of fiduciary duties for decision to construct coal plant. \\
\hline Australia & $\begin{array}{l}\text { McVeigh v Retail Employees } \\
\text { Superannuation Trust }\end{array}$ & $\begin{array}{l}\text { A pension fund member sued a superannuation fund, who } \\
\text { settled the case and agreed to take into considration climate } \\
\text { risks and reach net zero by } 2050 .\end{array}$ \\
\hline
\end{tabular}


Table A2. Cont.

\begin{tabular}{|c|c|c|}
\hline Country & Name of Case & Issue \\
\hline Brazil & $\begin{array}{c}\text { Public Prosecutor's Office v H Carlos } \\
\text { Schneider S/A Comércio e } \\
\text { Indústria \& Others. }\end{array}$ & Dispute about draining and clearing mangrove forest. \\
\hline Brazil & $\begin{array}{l}\text { Public Prosecutor's Office } \\
\text { v Oliveira \& Others. }\end{array}$ & Challenged low-tech sugar refining's impact on emissions. \\
\hline Brazil & $\begin{array}{l}\text { Sao Paulo Public Prosecutor's Office v } \\
\text { United Airlines. }\end{array}$ & Seeking airlines to use regional airports to offset emissions. \\
\hline Germany & Lliuya v RWE AG. & $\begin{array}{l}\text { Whether the German company that produces energy } \\
\text { contributes to climate change that caused damage to property. }\end{array}$ \\
\hline UK & The Kingsnorth Six Trial & $\begin{array}{l}\text { Greenpeace activists attempted to } \\
\text { shut down coal-power station. }\end{array}$ \\
\hline UK & $\begin{array}{l}\text { Heathrow Airport Ltd. } \\
\& \text { Ors v Garman \& Ors. }\end{array}$ & Protestors campaign near Heathrow Airport challenged. \\
\hline UK & Grainger plc and others v Nicholson. & $\begin{array}{l}\text { Employees claimed that climate change belief } \\
\text { is not merely an opinion. }\end{array}$ \\
\hline UK & $\begin{array}{l}\text { Deutsche Bank AG v Total } \\
\text { Global Steel Ltd. }\end{array}$ & $\begin{array}{l}\text { Breach of contract by using "surrendered" } \\
\text { Certified Emissions Reductions (CERs). }\end{array}$ \\
\hline UK & $\begin{array}{l}\text { CF Partners (UK) LLP v } \\
\text { Barclays Bank PLC. }\end{array}$ & Misuse of confidential information relating to carbon credits. \\
\hline Philippines & In re Greenpeace Southeast Asia et al. & Fossil fuel companies challenged for climate change impacts. \\
\hline New Zealand & $\begin{array}{l}\text { Royal Forest and Bird Protection } \\
\text { Society of New Zealand } \\
\text { Incorporated v Buller Coal Ltd. }\end{array}$ & $\begin{array}{l}\text { Dispute about whether regard should be given to } \\
\text { effects of climate change arising from use of coal. }\end{array}$ \\
\hline Canada & Weaver v Corcoran. & Dispute over articles about global warming. \\
\hline Canada & $\begin{array}{l}\text { Chicago Climate Exchange, Inc v } \\
\text { Montreal Green Exchange. }\end{array}$ & Challenge of a trademark application, as the name was similar \\
\hline Australia & $\begin{array}{c}\text { Australian Competition and Consumer } \\
\text { Commission v V8 Supercars } \\
\text { Australia Pty Ltd. }\end{array}$ & $\begin{array}{l}\text { Claims made about offsetting carbon emissions from } \\
\text { its V8 car racing series challenged. }\end{array}$ \\
\hline Australia & $\begin{array}{l}\text { Australian Competition and Consumer } \\
\text { Commission v Prime Carbon Pty Ltd. }\end{array}$ & $\begin{array}{l}\text { Challenge to representations about } \\
\text { carbon sequestration program. }\end{array}$ \\
\hline Australia & $\begin{array}{l}\text { Australian Competition and Consumer } \\
\text { Commission v Goodyear Tyres. }\end{array}$ & $\begin{array}{l}\text { Challenge to misleading consumers } \\
\text { about the environmental benefits. }\end{array}$ \\
\hline Australia & $\begin{array}{l}\text { Australian Competition and Consumer } \\
\text { Commission v GM Holden Ltd. }\end{array}$ & Green claims challenged in advertising Saab vehicles. \\
\hline Australia & $\begin{array}{l}\text { Australian Competition and Consumer } \\
\text { Commission v Global Green Plan Ltd. }\end{array}$ & $\begin{array}{c}\text { ACCC pursues court order for Green Plan to puchase } \\
\text { Renewable Energy Certificates. }\end{array}$ \\
\hline Australia & $\begin{array}{l}\text { Australian Competition and } \\
\text { Consumer Commission v De } \\
\text { Longhi Australia Pty Ltd. }\end{array}$ & De Longhi's environmental claims challenged by ACCC. \\
\hline
\end{tabular}

Extracted from: http:/ / climatecasechart.com/climate-change-litigation/non-us-case-category/corporations / (accessed on 9 November 2021).

\section{References}

1. District Court of The Hague. Milieudefensie and others v. Royal Dutch Shell; 26 May 2021 ECLI:NL:RBDHA:2021:5337; District Court of The Hague: The Hague, The Netherlands.

2. Available online: https:/ / climate-laws.org/ (accessed on 9 November 2021).

3. Available online: http://climatecasechart.com/climate-change-litigation/ (accessed on 9 November 2021).

4. Grantham Research Institute on Climate Change and the Environment and the Centre for Climate Change Economics and Policy. Global Trends in Climate Change Litigation: 2021 Snapshot. Policy Report July 2021. Available online: \&lt;https://www.lse.ac.uk/ 
granthaminstitute/wp-content/uploads/2021/07/Global-trends-in-climate-change-litigation_2021-snapshot.pdf10 (accessed on 9 November 2021).

5. Available online: https://unfccc.int/process-and-meetings/the-paris-agreement/the-paris-agreement/key-aspects-of-the-parisagreement (accessed on 31 March 2021).

6. International Institution for Sustainable Development. Making Finance Flows Consistent with the Paris Agreement. Commentary 11 February 2020. Available online: https:/ / sdg.iisd.org/commentary/policy-briefs/making-finance-flows-consistent-with-theparis-agreement/ (accessed on 31 March 2021).

7. Equity Generation Lawyers. Abrahams v Commonwealth Bank of Australia 2021. Available online: https://equitygenerationlawyers. com/abrahams-v-commonwealth-bank-of-australia-2021/ (accessed on 26 August 2021).

8. Federal Court of Australia, New South Wales Registry. Australasian Centre for Corporate Responsibility v. Santos NDS858/2021. Available online: https://www.comcourts.gov.au/file/Federal/P/NSD858/2021/actions (accessed on 9 November 2021).

9. Environment Victoria. Why We're Taking the EPA to Court. Available online: https://environmentvictoria.org.au/2021/09/23 / why-were-taking-the-epa-to-court/ (accessed on 23 September 2021).

10. Federal Court of Australia. Sharma v. Minister for the Environment [2021] FCA 560. Available online: http:/ / climatecasechart.com/ climate-change-litigation/non-us-case/raj-seppings-v-ley/ (accessed on 16 July 2021).

11. Federal Court of Australia. Kathleen O'Donnell v Commonwealth of Australia \& Ors; 22 July 2020; VID482/2020. Available online: https:/ / www.comcourts.gov.au/file/Federal/P/VID482/2020/actions (accessed on 23 September 2021).

12. Federal Court of Australia. McVeigh v. Retail Employees Superannuation Trust [2019] FCA 14. Available online: http: / / climatecasechart.com/climate-change-litigation/wp-content/uploads/sites/16/non-us-case-documents/2019/20190117_ NSD13332018_judgment-1.pdf (accessed on 20 October 2021).

13. Full Court of the Federal Court of Australia. Australian Conservation Foundation Incorporated v Minister for the Environment and Energy [2017] FCAFC 134. Available online: http:/ / climatecasechart.com/climate-change-litigation/non-us-case/australianconservation-foundation-incorporated-v-minister-for-the-environment-and-energy/ (accessed on 20 October 2021).

14. Land and Environment Court of New South Wales. Gloucester Resources Limited v. Minister for Planning [2019] NSWLEC 7. pp. 440-539. Available online: http://climatecasechart.com/climate-change-litigation/non-us-case/gloucester-resourceslimited-v-minister-for-planning/ (accessed on 20 October 2021).

15. United Nations. The Paris Agreement art 2. Available online: https://unfccc.int/sites/default/files/resource/parisagreement_ publication.pdf (accessed on 22 April 2019).

16. Land and Environment Court of New South Wales. Gloucester Resources Limited v. Minister for Planning [2019] NSWLEC 7 Preston CJ at 422. Available online: http:/ / climatecasechart.com/climate-change-litigation/non-us-case/gloucester-resources-limited-vminister-for-planning/ (accessed on 20 October 2021).

17. Lesley, H. The Rocky Hill Decision: A watershed for climate change action. J. Energy Nat. Resour. Law 2019, 37, 341-351.

18. Climate Change Authority. Targets and Progress Review; Final report; 9 February 2014. Available online: https://www. climatechangeauthority.gov.au/sites / default/files/2020-06/Target-Progress-Review/Targets\%20and\%20Progress\%20 Review\%20Final\%20Report.pdf (accessed on 20 October 2021).

19. WildEarth Guardians v US Bureau of Land Management. 870 F 3d 1222 (10th Cir, 2017), 1234. Available online: https: / casetext.com/ case/wildearth-guardians-v-us-bureau-of-land-mgmt-2 (accessed on 20 October 2021).

20. Potter, B. Landmark decision blocks Gloucester Resources coal mine in NSW. Australian Financial Review. Available online: https: / / www.afr.com/politics/landmark-decision-blocks-gloucester-resources-coal-mine-in-nsw-20190208-h1b0bo (accessed on 8 February 2019).

21. Carrick, D. Climate Change Takes Front Seat in NSW Court. ABC Law Report. Available online: https://www.abc.net.au/ radionational/programs/lawreport/10799006 (accessed on 12 February 2020).

22. Land and Environment Court of New South Wales. Strarford Coal Pty Ltd. v Minister for Planning [2019] NSWLEC 8. Available online: http:/ / www.austlii.edu.au/cgi-bin/viewdoc/au/cases/nsw/NSWLEC//2019/8.html (accessed on 12 February 2020).

23. Federal Court of Australia. McVeigh v. Retail Employees Superannuation Trust. [2019] FCA 14. Available online: http: / / climatecasechart.com/climate-change-litigation/wp-content/uploads/sites/16/non-us-case-documents/2018/20180921_ NSD13332018_complaint-1.pdf (accessed on 20 October 2021).

24. Commonwealth Government of Australia. Superannuation Industry (Supervision) Act 1993 (Cth).

25. Chance, C. Climate Change Test Case Settles: \$57BN Australian Super Fund Responds to Pressure on Climate Change Policy. Available online: https://www.cliffordchance.com/content/dam/cliffordchance/briefings/2020/11/climate-change-test-casesettle-client-briefing.pdf (accessed on 20 February 2020).

26. Grieve, C. Super Giants Funnel Billions into Fossil Fuels, Vote down Climate Push. Available online: https://www.smh.com.au/ business/banking-and-finance/super-giants-funnel-billions-into-fossil-fuels-vote-down-climate-push-20200211-p53zt1.html (accessed on 13 February 2020).

27. Yoo, T. Can You Sue Your Super Fund for Climate Change? Yahoo Finance AU. Available online: https://au.finance.yahoo.com/ news/sue-super-fund-climate-change-232121951.html (accessed on 13 February 2020).

28. Task Force on Climate-related Financial Disclosures, 2019 Status Report: Task Force on Climate-Related Financial Disclosures 2. Available online: https://www.fsb.org/2018/09/task-force-on-climate-related-financial-disclosures-status-report/ (accessed on 10 October 2020). 
29. Debelle., G. Climate Change and the Economy; Speech, Reserve Bank of Australia: Sydney, Australia, 14 October 2021.

30. APRA. APRA Releases Guidance on Managing the Financial Risks of Climate Change. Available online: https://www.apra.gov. $\mathrm{au} /$ news-and-publications/apra-releases-guidance-on-managing-financial-risks-of-climate-change (accessed on 22 April 2021).

31. Australian Council of Superannuation Investors. ACSI Launches New Climate Change Policy. Available online: https://acsi.org. au/media-releases/acsi-launches-new-climate-change-policy/ (accessed on 25 April 2021).

32. Armour, C.; Commissioner, Australian Securities; Investment Commission. Managing Climate Risk for Directors. Australian Institute of Company Director Magazine 2021 Back Editions February. Available online: https:/ / aicd.companydirectors.com.au/ membership/company-director-magazine/2021-back-editions/february/managing-climate-risk-for-directors (accessed on 1 February 2021).

33. New South Wales Supreme Court. Australian Securities and Investment Commission v Rich [2003] NSWSC 85.

34. New South Wales Law Reports. Daniels v Anderson (1995) 37 NSWLR 438.

35. High Court of Australia. Australian Securities and Investment Commission v Hellicar [2012] HCA 12.

36. New South Wales Supreme Court. Australian Securities and Investment Commission v Vines [2005] NSWSC 738.

37. Troiano, R. Climate change: Corporate liability, disclosure requirements and shareholders' remedies. Co. Secur. Law J. 2018, 26, 418-426.

38. Hutley, N. SC and Sebastian Harford-Davis. Climate Change and Directors Duties; Memorandum of Opinion, The Centre for Policy Development, 7 October 2016. ('Hutley 2016').

39. Hutley, N. SC and Sebastian Hartford Davis. Climate Change and Director's Duties; Supplementary Memorandum of Opinion; The Centre for Policy Development, 26 March 2019. ('Hutley 2019’).

40. Hutley, N. SC and Sebastian Hartford Davis, 'Climate Change and Director's Duties; Supplementary Memorandum of Opinion, The Centre for Policy Development, 23 April 2021. 18 ('Hutley 2021').

41. Australian Commonwealth Law Reports. Wyong Shire Council v Shirt, 146 CLR 40. 1980; 47-48.

42. di Lernia, C. Climate Risk Disclosure: Tracking the Uptake of the Taskforce on Climate-related Financial Disclosures (TCFD) Recommendations in the Australian Market. Co. Secur. Law J. 2020, 37, 470-471.

43. Foerster, A.; Peel, J. US fossil fuel companies facing legal action for misleading disclosure of climate risks: Could it happen in Australia? Aust. Environ. Rev. 2017, 32, 56-57.

44. Australian Government, Department of the Environment and Heritage, Australian Greenhouse Office. Climate Change Impacts \& Risk Management A Guide for Business and Government. Available online: https://sciencepolicy.colorado.edu/students/ envs_5120/australia_RCC_2006.pdf (accessed on 10 October 2020).

45. Task Force on Climate-Related Financial Disclosures. Recommendations of the Task Force on Climate-related Financial Disclosures; 14 December 2016. Available online: https:/ / assets.bbhub.io/company/sites/60/2020/10/16_1221_TCFD_Report_Letter.pdf (accessed on 7 October 2021).

46. Governance Institute of Australia. Climate Change Risk Disclosure: A Practical Guide to Reporting against ASX Corporate Governance Council's Corporate Governance Principles and Recommendations, (Report, February 2020) 9. Available online: https://www.governanceinstitute.com.au/advocacy/thought-leadership/climate-change-risk-disclosure/ (accessed on 25 August 2021).

47. Australian Securities and Investment Commission. Climate Risk Disclosure by Australia's Listed Companies; Report, 593, 3 September 2018. Available online: https: / / asic.gov.au/regulatory-resources/find-a-document/reports / rep-593-climate-riskdisclosure-by-australia-s-listed-companies / (accessed on 25 August 2021).

48. Baxt, R. Duties and Responsibilities of Directors' and Officers. The Australian Institute of Company Directors, 21 st ed, $2016 ; 72$.

49. Kenneth Hayne QC, 'What Kenneth Hayne says about climate change'. The Financial Review. Available online: https://www.afr. com/politics / federal/what-kenneth-hayne-says-about-climate-change-20191206-p53hiw (accessed on 19 December 2019).

50. Price, J. ASIC Commissioner, Climate Change; Speech, Centre for Policy Development: Sydney, Australia, 18 June 2018.

51. Available online: https://www.wri.org/insights/6-signs-progress-adoption-paris-agreement (accessed on 10 September 2021). 